\title{
Integrated Multi-Attribute Preference Analysis in Fisheries and Solar Power Symbiosis Areas: A Case Study in Cigu, Taiwan
}

\author{
Han-Shen Chen ${ }^{1,2, *(D)}$ and Hung-Yu Kuo ${ }^{1}$ (D) \\ 1 Department of Health Industry Technology Management, Chung Shan Medical University, Taichung 40201, \\ Taiwan; jason87523@yahoo.com.tw \\ 2 Department of Medical Management, Chung Shan Medical University Hospital, No. 110, Sec. 1, \\ Jianguo N. Rd., Taichung 40201, Taiwan \\ * Correspondence: allen975@csmu.edu.tw; Tel.: +886-04-2473-0022 (ext. 12225)
}

Citation: Chen, H.-S.; Kuo, H.-Y. Integrated Multi-Attribute Preference Analysis in Fisheries and Solar Power Symbiosis Areas: A Case Study in Cigu, Taiwan. Water 2021, 13, 3265. https:/ / doi.org/10.3390/w13223265

Academic Editors: Jenn Kai Tsai, Charles Tijus and Wei-Ling Hsu

Received: 7 October 2021

Accepted: 14 November 2021

Published: 17 November 2021

Publisher's Note: MDPI stays neutral with regard to jurisdictional claims in published maps and institutional affiliations.

Copyright: (c) 2021 by the authors. Licensee MDPI, Basel, Switzerland. This article is an open access article distributed under the terms and conditions of the Creative Commons Attribution (CC BY) license (https:// creativecommons.org/licenses/by/ $4.0 /)$.

\begin{abstract}
To achieve the 2025 Non-Nuclear Homeland goal and carbon emission mitigation target, the Taiwan government has been developing actively green and renewable energy with low carbon emissions. This study assessed the FSPS development project in the Cigu region of Tainan City to provide a thorough analysis toward making tradeoffs among ecosystem conservation, aquaculture, fisheries, and green power generation development. This study employs the choice experiment method and designs different attributes and levels to discuss the preferences of stakeholders in the policy development choices for ecosystem conservation and FSPS. The hope is that it can balance economic development and ecological conservation. The findings demonstrate that the tourists' marginal willingness to pay is low. The respondents then give importance to improving biodiversity. Finally, they prefer minimal changes to the status quo with the FSPS policy implementation. These findings can serve as a reference for decision making for regional sustainable development, aquaculture and fishery upgradation, and green power generation and exploitation.
\end{abstract}

Keywords: renewable energy; climate change; choice experiment; ecosystem conservation; solar energy generation

\section{Introduction}

Climate change has become a global concern [1], and the development of renewable energy is essential in mitigating climate change [2,3]. Hence, renewable energy has become pivotal for energy policies of many countries [4-7]. Taiwan has explicitly stipulated that its long-term greenhouse gas-reduction goal is to reduce $50 \%$ or more of its 2015 greenhouse gas emissions by 2050. According to Taipower [8] data, renewable energy development in Taiwan has prioritized wind and solar power generation; however, renewable energy constituted only $4.9 \%$ of the power generation structure in 2018. Accordingly, Taiwan's Agriculture Committee of the Executive Yuan approved the Two-Year Promotion Plan of Solar Photovoltaic Power Generation to accelerate the growth of renewable solar power generation. Taiwan is located in a subtropical area; hence, its sunlight exposure angle is suitable for the development of solar photovoltaic power generation. Therefore, to facilitate aquaculture and fisheries along with green power generation, fishery and solar power symbiosis (FSPS), which uses solar panels to generate electricity while raising fish by deploying solar photovoltaic facilities on the embankments of aqua farms, has been established [9].

The planned pilot areas of FSPS are in Changhua, Yunlin, Chia-I, Tainan, Kaohsiung, Pingtung, etc. in Taiwan, and the study area-the Cigu region of Tainan City (as shown in Figure 1) - has an aquaculture and fishery area of 4080 hectares. It has 1728 aquaculture farmer households and is an important aquaculture area of Taiwan [10]. Cigu is in the range of Taijiang National Park and has abundant geological and topographical patterns along with the largest number of black-faced spoonbills in winter globally (as shown in 
Figure 2). Activities such as seaborne oyster sheds, bird watching on wetlands, fishing village culture season, and oyster collecting experiences make Cigu a tourist attraction serving ecosystem experiences, cultural education, and recreational tourism (as shown in Figure 3). Spellman [11] indicated that the large-scale use of solar panels causes land deterioration and habitat loss in large areas and may have direct negative effects on wildlife [12]. Dhar et al. [13] also revealed that the development of solar power generation affects the environment, causing avian deaths, biodiversity loss, habitat loss, and visual impacts. With the implementation of FSPS, instead of renting out aqua farms to aquaculture farmers, landowners prefer renting them to solar power generation operators at a high price. Accordingly, aquaculture farmers using existing aqua farms must lease them from these operators, which exacerbates their future capacity to lease. Moreover, chemical pollution from the solar panels directly affects the aquaculture market; hence, local aquaculture farmers object to the project, underlining issues such as contract stability, high rent, and aquaculture product safety. Currently, Cigu has no consensus on the issue of ecosystem conservation and FSPS; further, the FSPS project to be implemented by the government may have deleterious effects on the ecosystems of the wetlands, aquaculture, and fisheries. Hence, the study area chosen is the Cigu region of Tainan City.

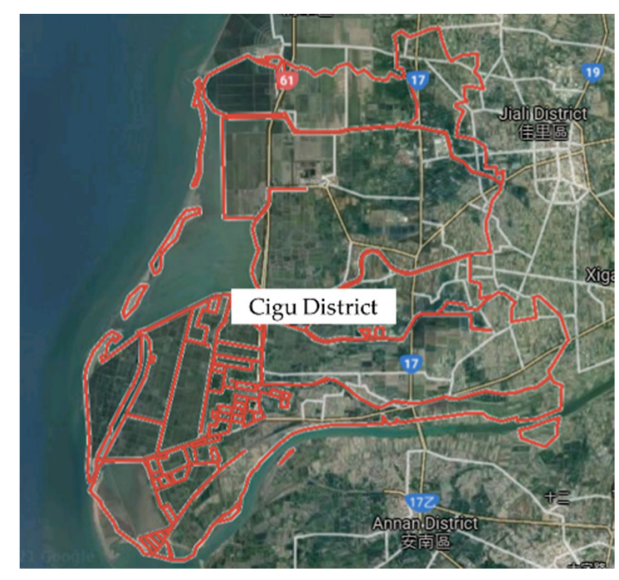

Figure 1. The area of Cigu District.

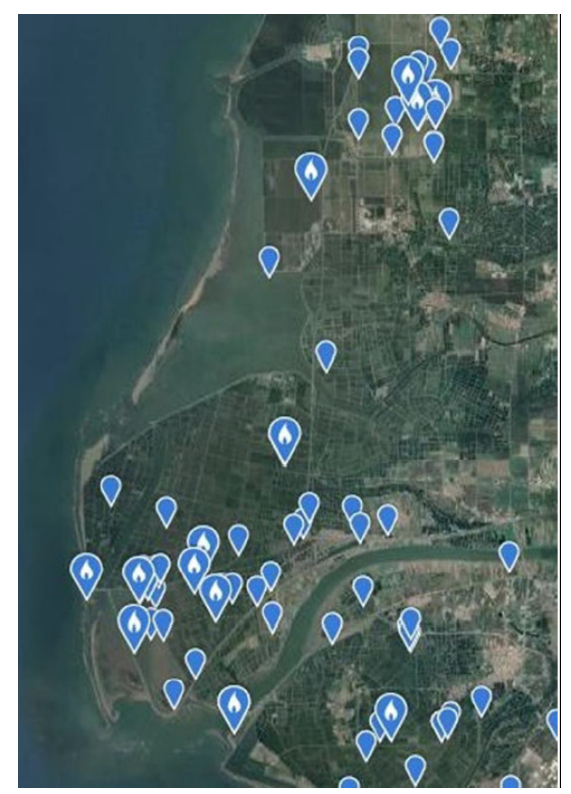

Figure 2. The distribution of the black-faced spoonbill. 


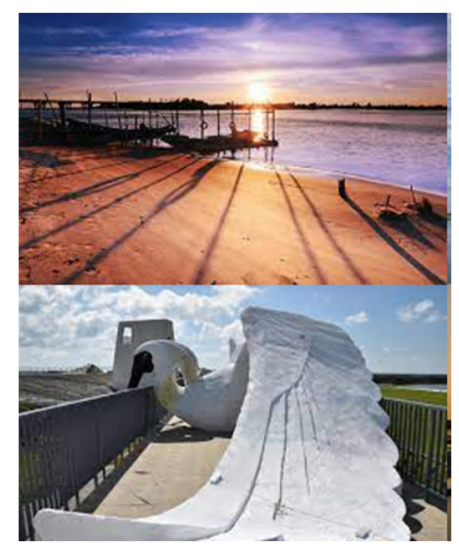

Figure 3. Attractions of the Cigu area.

The ecosystem is confronted with changes in regional development, climate change, and land use patterns [14]. In recent years, sustainable development integrating aspects including society, the ecosystem, the economy, and mechanisms has gradually been accepted by the public [15-18]. The Economics of Ecosystems and Biodiversity (TEEB) defined ecocompensation as a management method to protect an ecological environment and improve ecological services [19]. Muradian et al. [20] believed that nonmarket policy instruments, including taxation, subsidies, user payments, fines, and controls, can serve as incentives to provide good ecosystem services, appropriately reflecting the deserved compensation for its positive externality, penalizing the negative externality, or applying costs payable for its use. Ecocompensation or incentives may be provided to the stakeholders who adopt friendly management to achieve no net loss of the ecosystem service [21]. Ecocompensation is premised on a specific and explicit ecological value, which can be assessed using the choice experiment method (CEM) for any nonmarket property at different attribute levels [22]. CEM is based on hypothetical markets wherein respondents are required to make tradeoffs with the given choices, revealing the marginal utility for specific attributes; it is useful in determining the value of multiple characteristics and their relative importance to participants [23]. Therefore, this study employs CEM to establish a utility model for ecosystem conservation preference; it discusses tourists', local residents', and aquaculture farmers' preferences for policy development choices for ecosystem conservation and FSPS in Cigu using ecocompensation as the benefit assessment criterion. Finally, this study analyzes the issues reflected in the above model and provides a reference for decision making on aspects including ecosystem conservation, aquaculture and fisheries upgradation, and green power generation development.

Sustainable development is a core issue in the field of environmental and natural resources. Considering sustainable development and FSPS have never been seen before in Taiwan, this study adopts small-scale experiments to simulate different scenarios and land use patterns to provide a thorough assessment and analysis, which could facilitate tradeoffs among ecosystem conservation, aquaculture, fisheries, and green power generation. This study provides new insights by expanding the breadth and depth of research on regional ecosystems.

\section{Materials and Methods}

\subsection{Nonmarket Valuation}

In recent years, environmental economists and ecologists have been continuously studying the quantification tools and assessment methods for nonmarket goods to measure the economic benefit of natural environment conservation. Among the common assessment methods, nonmarket goods can be classified as those using revealed preference (RP) and stated preference (SP). RP means to survey the actual chosen behaviors or results that have already occurred in the target market directly via questionnaires. Common assessment methods include the traveling cost and hedonic price methods. Conversely, SP can survey 
the results that have not occurred in the target market to obtain the respondents' choice preference data, and it uses the contingent valuation method (CVM) and CEM. Mark and Swait [24] revealed that SP can amend the disadvantages of RP, such as insufficient collinearity and the variation degree of variables, so parameter assessment can be more explanatory, reflecting the respondents' actual preferred choices; therefore, SP is a main value study method in the natural environment field. Applying CVM has some limitations [25]; accordingly, CEM has gradually gained importance in measuring the value of nonmarket goods [26]. While CVM can only consider the characteristic attributes of natural resources as goods as a whole and conduct single value analysis, CEM can assess multiple attributes and levels, combine different alternative schemes according to the important characteristics of nonmarket goods or services, and allow the respondents to select suitable alternative schemes based on their preferences via the choice set of different scenario assumptions to avoid assessment-biased errors [27]. Therefore, CEM can better solve the profit and loss comparison issue of the multiple ecological attributes of ecosystem services and demonstrate the preference for the same [28]. Hence, CEM has been widely used in discussions on many topics.

Rulleau et al. [29] adopted CEM to investigate Alsace of France residents' preferences for ecosystem services of wetlands. Liu and Yang [30] adopted CEM to assess the tourists' preferences and willingness to pay (WTP) for the management of a black-faced spoonbill conservation area. $\mathrm{Xi}$ et al. [31] used a random parameter logit to study the Caofeidian Coastal Wetland of China (Mainland) and revealed that respondents with higher education levels have relatively high WTP for wetland conservation. Huang et al. [32] adopted CEM to discuss tourists' views toward the value of the landscape and ecosystem services of the Kaumei Wetland. Owuor et al. [33] adopted CEM to analyze Kenyan residents' preferences in Africa for the biodiversity and ecosystem services of mangrove forests. Mao et al. [34] used CEM to measure the preferences of Chinese residents for wetland management. Hassan et al. [35] used CEM to study rural and urban residents' views of Southwest Malaysia toward wetland protection. Kim et al. [36] adopted CEM to discuss the acceptance preference of Korean residents toward wind power generation.

Accordingly, these studies indicate that CEM can be used to establish a multi-attribute utility function between natural resources and the environment. CEM can also be used to estimate the economic value of environmental resources, goods, and services, including by conducting value measurements of endangered species conservation and the improvement, service planning, and value estimation of recreational facilities, as well as preference gauging for a wetland's ecological area plan. Particularly, in biodiversity conservation, conservation preferences for different endangered species and improvements in endangered species classification are the main characteristics of species conservation, and the establishment of a restoration fund system is an important consideration for conservation policies. Hence, referring to relevant literature, this study adopts CEM as the theoretical basis for the construction of the scheme characteristic attributes and constructs the multiattribute utility function, management scheme assessment mode, and architecture of Cigu. Meanwhile, via the choice sets of different scenario assumptions, this study assesses the preferences of tourists, local residents, and aquaculture farmers for ecosystem functions so that the respondents can choose suitable alternative schemes according to their preferences and assess the economic benefits of the schemes.

\subsection{Choice Experiment Design}

The questionnaire design covers three parts. The first part includes knowledge and conservation preferences to discuss respondents' knowledge about the environmental impacts of FSPS and their willingness for conservation. The questions delve into the respondents' knowledge of environmental damage caused by solar panels and the influence of FSPS on aquaculture while surveying the tendency and preference for future ecosystem conservation, from which the respondents' basic knowledge about the conservation of the region can be obtained. The second part includes preferences for ecosystem conservation 
policies, which adopts CEM to discuss the respondents' preferences for the ecosystem conservation policies in Cigu and their willingness for compensation. The attributes include "biodiversity", "land use pattern", "FSPS coverage ratio", "coastal landscape" and "ecocompensation fund". The permutation and combination of different attributes and level values can produce $405(3 \times 3 \times 3 \times 3 \times 5)$ scenario combinations for respondents to choose from. In the actual survey, however, to reduce the burden of the respondents, this study adopts an orthogonal design method to reduce 405 combinations to 25 alternative schemes and 1 status quo scheme; then, after removing 18 unreasonable ones, 15 choice sets were produced. For the credibility of the permutation changes of the choice sets, each respondent must choose one out of three schemes, including two different alternative schemes and the status quo scheme from three choice sets (as shown in Tables 1 and 2). Therefore, each questionnaire included two choice sets; hence, seven versions of questionnaires were produced. The third part includes basic information about the individuals, including gender, age, education background, monthly personal income, and preference for ecosystem conservation, among other questions. The connotations of the attributes are explained as follows:

Table 1. Questionnaire design example.

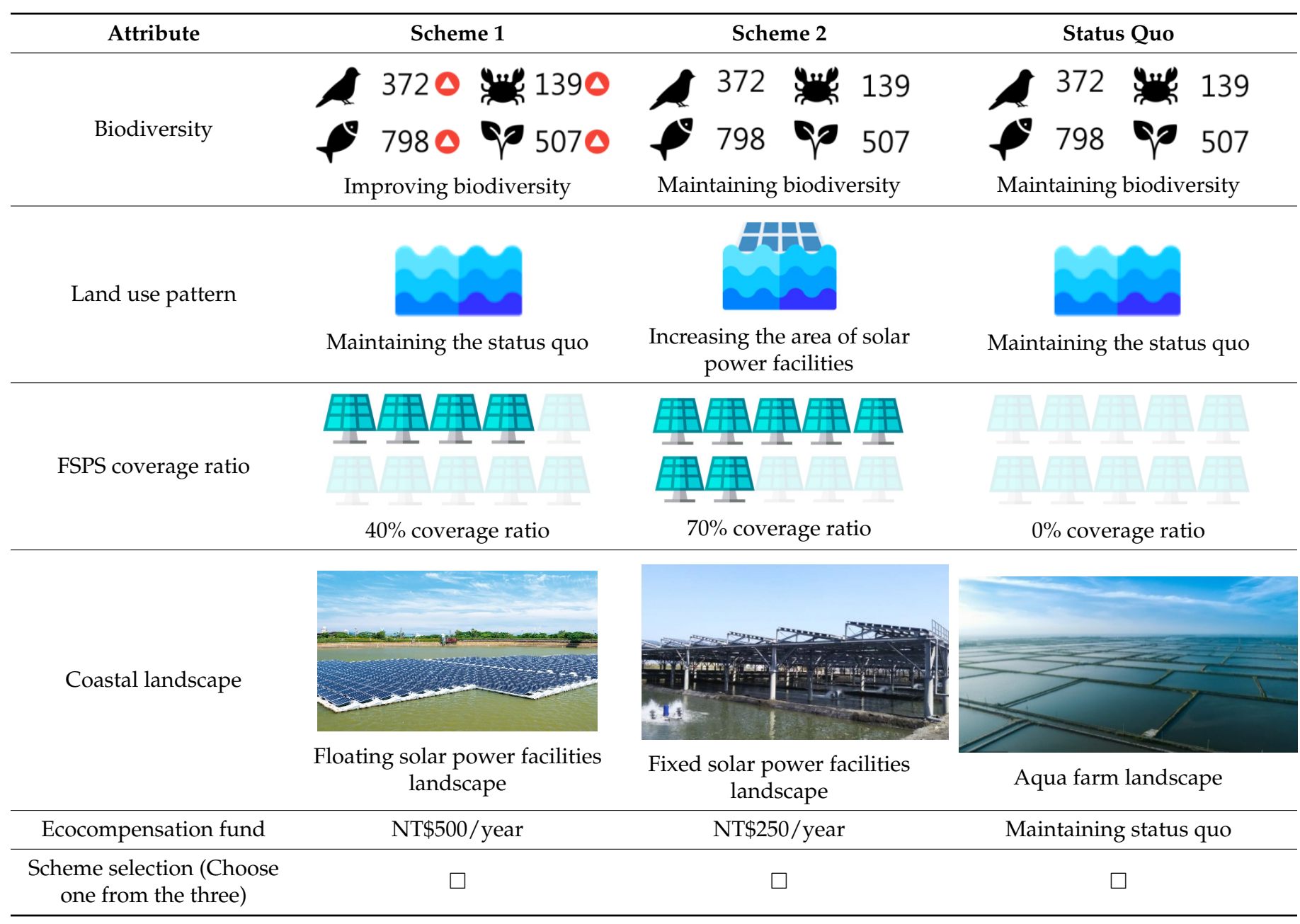


Table 2. Questionnaire design example.

\begin{tabular}{ccccccc}
\hline No. & $\mathbf{1}$ & $\mathbf{3}$ & $\mathbf{6}$ & $\mathbf{1 2}$ & $\mathbf{1 7}$ & $\mathbf{2 5}$ \\
\hline 3 & $1 \times 3$ & & & & & \\
6 & $1 \times 6$ & $3 \times 6$ & & & & \\
12 & $1 \times 12$ & $3 \times 12$ & $6 \times 12$ & & & \\
17 & $1 \times 17$ & $3 \times 17$ & $6 \times 17$ & $12 \times 17$ & & \\
25 & $1 \times 25$ & $3 \times 25$ & $6 \times 25$ & $12 \times 25$ & $17 \times 25$ & \\
\hline
\end{tabular}

\subsubsection{Biodiversity}

The coastal wetland is a highly productive ecosystem [37-39]; hence, excessive exploitation of the coastal ecosystems has drawn many scholars' concern over recent years [33,40-42]. Biodiversity reflects the range and diversity of animals and plants in the wetland and is often used as an indicator for assessing coastal ecosystems [33,35,38]. Suziana [43] adopted CEM to discuss the conservation of the Malaysian wetland ecosystem, with attributes including environmental conditions, biodiversity, recreational services, flood control, and subsidy changes. The FSPS policy to be implemented by the Taiwan government pays attention to developing green energy generation facilities without affecting the existing fishery production, and ensuring that the aquaculture production environment is optimized to reduce the labor input. Additionally, if biodiversity cannot be destroyed when developing the FSPS, it is more perfect. In summary, this study discusses whether the animals and plants in the study area are protected or recovered based on the status quo of development.

\subsubsection{Land Use Patterns}

Changes in land use patterns can gradually weaken ecosystem functions [44]. Hence, evaluating the preference of the stakeholders in the study area for land use patterns is helpful for regional development and the adjustment of land usage policies [45,46]. Erb [47] divided land usage changes into two types, namely pattern change, such as aquafarm to house, and intensity change, such as the change of production (value or quantity) of an aquafarm by unit area and unit time. In Taiwan, the development of limited land area requires consideration of land use patterns. This study adopts land use patterns as an attribute to discuss the preferences for the distribution of land use patterns in Cigu, particularly for "increasing afforestation area" and "increasing the area of solar power facilities."

\subsubsection{Fisheries and Solar Power Symbiosis Coverage Ratio}

Currently, wetland conservation and FSPS are not balanced, and this study's findings on the measurement of compatibility between economic development and sustainable resources are still incomplete. Therefore, this study attempts to discuss the preferences of tourists, local residents, and aquaculture farmers regarding policy development for wetland ecosystem conservation and FSPS using CEM. In the simulation test for actual FSPS by Taiwan Aquatic Product Laboratory (APL), conducted in 2019, the coverage ratios adopted were $0 \%, 40 \%$ and $70 \%$, and the test results showed that clam growth was best for the $40 \%$ coverage ratio. Clam growth for the $40 \%$ coverage ratio was better than the growth observed for the $70 \%$ coverage ratio; the growth for the $0 \%$ coverage ratio ranked last. Moreover, it was found that FSPS equipment can effectively lower the temperature in summer and prevent it from dropping sharply in winter. The Working Principles for FSPS Test Project Plan stipulates that the area of the arranged solar facilities shall not be more than $40 \%$ of the land area for the test. However, if the actual case is the same as the test results from the APL, the productivity of the aquafarms with FSPS equipment will be better than farms without the equipment. The production values of green power generation, aquaculture, and fisheries can be increased simultaneously. In summary, this study adopts the " $0 \%$ coverage ratio" as the status quo according to the test arrangement by the APL and the two-level values of " $40 \%$ and $70 \%$ coverage ratios" for discussion. 


\subsubsection{Coastal Landscape}

Under FSPS, solar photovoltaic facilities are arranged on the water or shore area to create an environment that is friendly to the fisheries. The arrangement methods include fixed (rack-type) arrangements and floating-type arrangements, based on structural differences. In the fixed type, the support structure of the solar panels is piled into the stratum below the water to construct foundation piles, whereas in the floating type, floating platforms are installed on the water to load the solar panels onto. Compared with the solar photovoltaic facilities that are fixed on land, the floating type has the following advantages: low installation cost, reduction of water evaporation, and reduction of water body eutrophication; furthermore, water can help cool down the solar photovoltaic system to prolong its service life [48-51]. However, different installation modes can cause different coastal landscapes. Wen et al. [52] argue that although wind power plants reduce carbon emissions, their visual influence on the landscape often leads to objections from local community residents. Lee et al. [53] shows that respondents believe that the visual influence and ecosystem damage from wind power plants are worse than noise pollution. Because Cigu is a sightseeing spot, it is very necessary to include this factor. Accordingly, this study believes that the installation mode of FSPS will affect the coastal landscape; hence, it discusses the aquafarm landscape, the fixed solar power facilities landscape, and the floating solar power facilities landscape.

\subsubsection{Ecocompensation Fund}

According to existing studies, ecocompensation can be roughly divided into cash and environmental compensation [15,54]. Westerberg et al. [55] adopted CEM to assess tourist preferences for offshore wind power generation, and their findings show that tourists willingness to accept cash compensation is reduced with increased distance between the offshore wind power generators and the seashore. Moreover, if additional environment policies are in place, the acceptable distance of the respondents for the wind power generators will be reduced, so the environmental policies can be considered a substitute for cash compensation [54]. According to the survey findings of the ecocompensation assessment patterns, this study sets level values, including "0", "NT\$250/year", "NT\$500/year", "NT\$750/year" and "NT\$1000/year", to be chosen by the respondents. Furthermore, with respect to environmental compensation, to provide directions for future actions in the area for study, the preferred options for "ecological remediation" and "ecosystem creation" are discussed.

\subsection{Model Selection and Analysis}

This study designs questionnaires to survey the respondents' preferences for ecosystem conservation and FSPS in Cigu, and the choice sets include the scheme choices for them. Assume the utility function of each respondent, as shown in Formula (1):

$$
U_{i j}=U\left(X_{j}, P_{j}, \varepsilon_{i j}\right)
$$

For any respondent $i(i=1,2,3, \ldots \mathrm{n})$, utility is obtained from choosing an alternative scheme $j$ for ecosystem conservation and $\operatorname{FSPS}\left(j=\mathrm{A}, \mathrm{B}\right.$, and C). $X_{j}$ is an attribute vector describing alternative scheme $j$, and $P_{j}$ is the monetary cost (or price) relevant to the alternative scheme $j$. The indirect utility function can be divided into two parts, as shown in Formula (2):

$$
U_{i j}=V_{j}+\varepsilon_{i j}=V\left(X_{j}, P_{j}\right)+\varepsilon_{i j}
$$

$V_{j}$ is the observable part of the indirect utility function obtained when respondent $i$ chooses alternative scheme $j$, and $\varepsilon_{i j}$ is the random (unobservable) part of the function. According to random utility theory, it is assumed that when the indirect utility obtained by respondent $i$ choosing alternative scheme $j$ from choice set $t$ is greater than that obtained 
from any other alternative scheme $k$, the respondent $i$ will choose alternative scheme $j$ rather than alternative scheme $k$, as shown in Formula (3):

$$
U_{i j}>U_{i k} \rightarrow V_{j}+\varepsilon_{i j}>V_{k}+\varepsilon_{i k}, \forall k \neq j ; j, k \in t
$$

$U_{i k}$ is the indirect utility value when respondent $i$ chooses alternative scheme $k$, meaning respondent $i$ prefers the alternative scheme $j$ to the other alternative scheme $k$, i.e., the degree of satisfaction from alternative scheme $j$ is higher than that from alternative scheme $k$. If the utility from alternative scheme $j$ is greater than that from any other alternative scheme in choice set $t$, the result $y_{i}=y_{t}$ is observed. Therefore, the probability that respondent $i$ chooses scheme $j$ instead of $k$ can be expressed with utility (i.e., the observable and error parts of the utility function), as shown in Formula (4):

$$
P\left(y_{i}=j t\right)=P\left(U_{i j}>U_{i k}\right), \forall k \neq j ; j, k \in t=P\left(V_{j}+\varepsilon_{i j}>V_{k}+\varepsilon_{i k}\right), \forall k \neq j ; j, k \in t=P\left(\varepsilon_{i k}-\varepsilon_{i j}<V_{j}-V_{k}\right), \forall k \neq j ; j, k \in t
$$

Let us assume the respondent obtains utility from ecosystem conservation and FSPS in Cigu's policy according to the scheme attribute $(Z)$ and social economic and psychological characteristics (S). The choice utility function can be divided into two parts. First, there is the determinacy or observable part $(\mathrm{V})$ of utility; $\mathrm{V}$ is the attribute vector describing ecosystem conservation and the FSPS policy in Cigu, which influences the respondents' preferences and is supplemented by socioeconomic characteristics and the respondents' social psychological characteristics (S). Second, we have the unobservable factors (error terms) $(\varepsilon)$, because they may also influence the respondents' preferences. To estimate parameters and calculate the influence of welfare, the utility function is often assumed to be linear. The utility of each option can be divided into observable and unobservable factors (error terms), as shown in Formula (5):

$$
P_{i}(j)=\operatorname{Pr}\left\{V\left(Z_{j}, S_{i}\right)+\varepsilon_{i j} \geq V\left(Z_{k}, S_{i}\right)+\varepsilon_{i k}, \text { s.t. } \forall k \neq j ; j, k \in t\right\}
$$

To estimate the probability functions and observable parameters in Formula (5), the multinomial logit (MNL) model has become the most commonly used measurement model for CE. MNL contains only particular characteristics as explanatory variables, and the model parameters are independent of the choice of alternative scheme $j$. Therefore, it is assumed that $X_{j}$ is the combination of particular attribute levels in $j$, and $\beta_{x}$ is the preference parameter relevant to $X_{j}$, so the indirect utility function of scheme $j$ chosen by the respondent is shown in Formula (6):

$$
U_{i j}=\alpha_{j}+X^{\prime} s s_{j}+{ }_{x} P^{\prime} s s_{j}+\varepsilon_{p}
$$

Assuming a fixed price coefficient and allowing differences in other coefficients, the utility of scheme $j$ chosen by the respondent is greater than the probability of any other alternative scheme in choice set $t$, as shown in Formula (7):

$$
P\left(y_{i}=j \mid t\right)=\frac{\exp \left(\alpha_{j}+X^{\prime} s s_{j}+P_{j}^{\prime} s s_{p}\right)}{\sum_{h \in t} \exp \left(\alpha_{h}+X_{h}^{\prime} s s_{x}+P_{h}^{\prime} s s_{p}\right)}
$$

In the formula, $\alpha$ stands for the alternative specific constant (ASC), and this model can measure the influence of every particular variable on the respondent's choice.

MNL adopts maximum likelihood estimation to assess the particular chosen data; this study assumes that the sample is composed of $i$ number of respondents, each one has $t$ choices, and each choice set is composed of $j$ number of alternative schemes. It is assumed that $\delta_{i j t}$ is an explanatory variable as shown in Formula (8):

$$
\left\{\begin{array}{c}
\delta_{i j t}=1: \text { scheme } j \text { chosen by respondents } i \text { from the choice set } t \\
0: \text { others }
\end{array}\right.
$$

Hence, the likelihood estimation function of the corresponding MNL model is shown in Formula (9):

$$
L\left(s s_{x}, s s_{p}\right)=\prod_{i=1}^{I} \prod_{t=1}^{T} \prod_{j=1}^{J}\left(P\left(y_{i}=j \mid t\right)\right)^{\delta_{i j t}}
$$


This study assesses every respondent's WTP for ecocompensation for ecosystem conservation and FSPS. Therefore, the marginal value of each attribute from the initial (status quo) to the final level (after the implementation of protective measures) can be deduced. Hence, the marginal WTP (MWTP), which is relevant to the quality of the improvement attribute " $\alpha$," can be calculated in the formula shown in (10):

$$
W T P_{\alpha}=-\frac{s s_{\alpha}}{s s_{p}}
$$

WTP is the marginal price the respondents are willing to pay; $\beta_{\alpha}$ is the estimation coefficient of the nonprice choice attribute; and $\beta_{p}$ is the estimation coefficient of the price choice attribute.

\section{Results}

\subsection{Data Collection and Descriptive Statistics}

The survey was conducted through one-on-one interviews to reduce the respondents' biased errors and to assist in answering the questions. Additionally, considering the continuous spread of COVID-19 and to reduce the contact time between the interviewers and respondents, QR codes of the online questionnaires were issued onsite with a brief introduction by the interviewer about the background, motivation, and study purpose. The respondents were allowed to inquire regarding doubtful questions; then, each respondent could answer the questions at the time and place of their choice to reduce the respondents' panic because of COVID-19, ensuring correct answers. Alalwan [56] has indicated that online surveys allow the respondents to provide their views more effectively and reduce errors in answering the questionnaires. This study issued 1142 questionnaires, and 974 valid responses were received, with a valid questionnaire recovery ratio of $85.2 \% ; 400,405$, and 169 valid questionnaires were from tourists, local residents, and aquaculture farmers, respectively. The findings are shown in Table 3.

The findings concerning ecological knowledge and preferences for ecosystem conservation are shown in Table 4, and knowledge about FSPS and ecocompensation is measured with a 7-point Likert scale. Tourists, local residents, and aquaculture farmers were asked about their degree of agreement with each question, choosing from 1 "strongly disagree" to 7 "strongly agree". According to the findings revealed in Table 4, the tourists, local residents, and aquaculture farmers know about FSPS and ecocompensation to a limited extent, and the local residents' and aquaculture farmers' knowledge of Cigu is greater than that of the tourists. Hence, it is recommended that the relevant authorities, such as the Tourism Bureau and the Agriculture Committee, enhance the promotion and explanation of FSPS (e.g., sticking posters, playing videos, explaining by guides) in recreational scenic spots to improve tourists' knowledge.

Table 3. Demographic information.

\begin{tabular}{|c|c|c|c|c|c|c|c|}
\hline \multirow[t]{2}{*}{ Variable } & \multirow[t]{2}{*}{ Item } & \multicolumn{2}{|c|}{$\begin{array}{l}\text { Tourists } \\
(\mathrm{N}=400)\end{array}$} & \multicolumn{2}{|c|}{$\begin{array}{l}\text { Local Residents } \\
\qquad(\mathrm{N}=405)\end{array}$} & \multicolumn{2}{|c|}{$\begin{array}{l}\text { Aquaculture Farmers } \\
\qquad(\mathrm{N}=169)\end{array}$} \\
\hline & & $\mathbf{N}$ & $\%$ & $\mathbf{N}$ & $\%$ & $\mathbf{N}$ & $\%$ \\
\hline \multirow{2}{*}{ Gender } & Male & 203 & $50.8 \%$ & 205 & $50.6 \%$ & 141 & $83.4 \%$ \\
\hline & Female & 197 & $49.2 \%$ & 200 & $49.4 \%$ & 28 & $16.6 \%$ \\
\hline \multirow{7}{*}{ Age (years) } & Under 19 & 45 & $11.2 \%$ & 7 & $1.8 \%$ & 0 & $0.0 \%$ \\
\hline & $20-29$ & 82 & $20.4 \%$ & 9 & $2.3 \%$ & 0 & $0.0 \%$ \\
\hline & 30-39 & 97 & $24.3 \%$ & 83 & $20.6 \%$ & 14 & $8.3 \%$ \\
\hline & $40-49$ & 71 & $17.8 \%$ & 105 & $25.6 \%$ & 52 & $30.8 \%$ \\
\hline & 50-59 & 55 & $13.7 \%$ & 84 & $20.8 \%$ & 58 & $34.3 \%$ \\
\hline & $60-69$ & 32 & $8.1 \%$ & 71 & $17.6 \%$ & 30 & $17.8 \%$ \\
\hline & 70 above & 18 & $4.5 \%$ & 46 & $11.3 \%$ & 15 & $8.9 \%$ \\
\hline
\end{tabular}


Table 3. Cont.

\begin{tabular}{|c|c|c|c|c|c|c|c|}
\hline \multirow[t]{2}{*}{ Variable } & \multirow[t]{2}{*}{ Item } & \multicolumn{2}{|c|}{$\begin{array}{l}\text { Tourists } \\
(\mathrm{N}=400)\end{array}$} & \multicolumn{2}{|c|}{$\begin{array}{l}\text { Local Residents } \\
\qquad(\mathrm{N}=405)\end{array}$} & \multicolumn{2}{|c|}{$\begin{array}{l}\text { Aquaculture Farmers } \\
\qquad(\mathrm{N}=169)\end{array}$} \\
\hline & & $\mathbf{N}$ & $\%$ & $\mathbf{N}$ & $\%$ & $\mathbf{N}$ & $\%$ \\
\hline \multirow{5}{*}{ Education level } & Junior high school & 33 & $8.2 \%$ & 67 & $16.6 \%$ & 52 & $30.8 \%$ \\
\hline & $\begin{array}{l}\text { Senior high/vocational } \\
\text { school }\end{array}$ & 68 & $17.0 \%$ & 156 & $38.4 \%$ & 45 & $26.6 \%$ \\
\hline & Junior college & 105 & $26.2 \%$ & 102 & $25.2 \%$ & 39 & $23.1 \%$ \\
\hline & Bachelor's degree & 139 & $34.8 \%$ & 52 & $12.8 \%$ & 26 & $15.4 \%$ \\
\hline & Master's degree \& above & 55 & $13.8 \%$ & 28 & $7.0 \%$ & 7 & $4.1 \%$ \\
\hline \multirow{6}{*}{$\begin{array}{l}\text { Average personal income } \\
\text { per month }\end{array}$} & NT $\$ 20,000$ and below & 73 & $18.2 \%$ & 59 & $14.6 \%$ & 5 & $3.0 \%$ \\
\hline & NT $\$ 20,001-40,000$ & 122 & $30.2 \%$ & 115 & $28.2 \%$ & 17 & $10.1 \%$ \\
\hline & NT\$40,001-60,000 & 99 & $24.8 \%$ & 92 & $22.8 \%$ & 89 & $52.7 \%$ \\
\hline & NT\$60,001-80,000 & 58 & $14.6 \%$ & 92 & $22.8 \%$ & 46 & $27.2 \%$ \\
\hline & NT $\$ 80,001-100,000$ & 30 & $7.6 \%$ & 26 & $6.4 \%$ & 8 & $4.7 \%$ \\
\hline & NT\$100,000 and above & 18 & $4.6 \%$ & 21 & $5.2 \%$ & 4 & $2.4 \%$ \\
\hline \multirow{2}{*}{$\begin{array}{l}\text { Participation in } \\
\text { environmental groups }\end{array}$} & Yes & 29 & $7.2 \%$ & 13 & $3.2 \%$ & 3 & $1.8 \%$ \\
\hline & No & 371 & $92.8 \%$ & 392 & $96.8 \%$ & 166 & $98.2 \%$ \\
\hline \multirow{2}{*}{$\begin{array}{c}\text { Preference for } \\
\text { ecocompensation }\end{array}$} & Ecological remediation & 299 & $74.7 \%$ & 307 & $75.7 \%$ & 137 & $81.1 \%$ \\
\hline & Ecosystem creation & 101 & $25.3 \%$ & 98 & $24.3 \%$ & 32 & $18.9 \%$ \\
\hline
\end{tabular}

Table 4. Respondents' ecological knowledge and preferences for ecosystem conservation.

\begin{tabular}{|c|c|c|c|c|c|c|c|}
\hline \multirow{2}{*}{ Item } & \multirow{2}{*}{ Options } & \multicolumn{2}{|c|}{ Tourists } & \multicolumn{2}{|c|}{ Local Residents } & \multicolumn{2}{|c|}{ Aquaculture Farmers } \\
\hline & & $\mathbf{N}$ & $\%$ & $\mathbf{N}$ & $\%$ & $\mathbf{N}$ & $\%$ \\
\hline \multirow{3}{*}{$\begin{array}{l}\text { Do you believe that "solar power } \\
\text { generation" harms the environment? }\end{array}$} & Yes & 325 & $81.2 \%$ & 345 & $85.1 \%$ & 148 & $87.8 \%$ \\
\hline & No & 63 & $15.8 \%$ & 45 & $11.2 \%$ & 15 & $9.1 \%$ \\
\hline & No idea & 12 & $3.0 \%$ & 15 & $3.7 \%$ & 5 & $3.1 \%$ \\
\hline \multirow{2}{*}{$\begin{array}{c}\text { Have your heard that the government } \\
\text { will develop "Fisheries and Solar } \\
\text { Power Symbiosis (FSPS)" in the Cigu } \\
\text { region of Tainan? }\end{array}$} & Yes & 322 & $80.6 \%$ & 353 & $87.1 \%$ & 160 & $94.5 \%$ \\
\hline & No & 78 & $19.4 \%$ & 52 & $12.9 \%$ & 9 & $5.5 \%$ \\
\hline \multirow{3}{*}{$\begin{array}{l}\text { Do you believe that the development of } \\
\text { "FSPS" will influence the production } \\
\text { output of the aquaculture and fisheries? }\end{array}$} & Yes & 327 & $81.8 \%$ & 347 & $85.6 \%$ & 155 & $92.0 \%$ \\
\hline & No & 61 & $15.2 \%$ & 45 & $11.2 \%$ & 11 & $6.7 \%$ \\
\hline & No idea & 12 & $3.0 \%$ & 13 & $3.2 \%$ & 2 & $1.3 \%$ \\
\hline \multirow{3}{*}{$\begin{array}{l}\text { Do you believe that the construction of } \\
\text { the FSPS facilities will influence the } \\
\text { surrounding ecosystem? }\end{array}$} & Yes & 327 & $81.7 \%$ & 337 & $83.3 \%$ & 147 & $86.7 \%$ \\
\hline & No & 53 & $13.2 \%$ & 58 & $14.4 \%$ & 20 & $11.6 \%$ \\
\hline & No idea & 20 & $5.1 \%$ & 9 & $2.3 \%$ & 3 & $1.7 \%$ \\
\hline \multirow{4}{*}{$\begin{array}{l}\text { Do you agree with the prevention or } \\
\text { mitigation of the hazards to the } \\
\text { ecosystem via "ecocompensation"? }\end{array}$} & Yes & 283 & $70.8 \%$ & 297 & $73.4 \%$ & 125 & $74.2 \%$ \\
\hline & No & 60 & $14.9 \%$ & 45 & $11.2 \%$ & 20 & $12.0 \%$ \\
\hline & No idea & 57 & $14.3 \%$ & 62 & $15.4 \%$ & 23 & $13.8 \%$ \\
\hline & & $\begin{array}{l}\text { Average } \\
\text { value }\end{array}$ & $\begin{array}{l}\text { Standard } \\
\text { deviation }\end{array}$ & $\begin{array}{l}\text { Average } \\
\text { value }\end{array}$ & $\begin{array}{l}\text { Standard } \\
\text { deviation }\end{array}$ & $\begin{array}{l}\text { Average } \\
\text { value }\end{array}$ & $\begin{array}{l}\text { Standard } \\
\text { deviation }\end{array}$ \\
\hline How well do you know about "FSPS"? & & 5.13 & 0.47 & 5.32 & 0.68 & 5.47 & 0.58 \\
\hline $\begin{array}{l}\text { How well do you know about } \\
\text { "ecocompensation"? }\end{array}$ & & 5.17 & 0.62 & 5.22 & 0.91 & 5.32 & 0.66 \\
\hline
\end{tabular}


Further, the environmental group participants constitute less than $10 \%$ of all three types of respondents. Most respondents have heard that the government will implement FSPS in Cigu. Approximately $80 \%$ of the respondents believe that solar power generation featuring green energy will harm the environment and that the equipment used by FSPS will affect the surrounding ecosystem. However, although the respondents believe that FSPS may damage the environment, approximately $70 \%$ of them agree with preventing or mitigating the hazards to the ecosystem via ecocompensation. Hence, although developing the FSPS must harm the environment, most people think ecocompensation can balance it. This is consistent with the study findings of Muradian et al. [20] and Kumar et al. [21] that ecocompensation or rewards can be used to balance ecosystem protection and exploitation.

This study analyzes the attribute combinations of seven preferences of the respondents for FSPS (including the status quo), and the findings are shown in Table 5. The most preferred combination for FSPS by the respondents is "improving biodiversity, maintaining the status quo of the land use pattern, $40 \%$ FSPS coverage ratio, floating solar power facilities landscape, and the ecocompensation fund of NT $\$ 500 /$ year". The less preferred combination is "maintaining biodiversity, increasing afforestation area, FSPS $40 \%$ coverage ratio, floating solar power facilities landscape, and the ecocompensation fund of NT $\$ 250$ /year". The least preferred is "improving biodiversity, maintaining the status quo of the land usage pattern, $40 \%$ FSPS coverage ratio, fixed solar power facilities landscape, and the ecocompensation fund of NT\$1000/year". This study deduces that fixed solar power facilities are built on land, so they significantly affect the landscape; additionally, the installation of the machine modules may influence the planning of the tourist routes and dwelling quality of the residents and aquaculture farmers. Hence, the tourists, local residents, and aquaculture farmers do not prefer them. The same parts are "improving biodiversity", "maintaining the status quo of the land use pattern" and " $40 \%$ FSPS coverage ratio", which means that most respondents prefer these attributes.

Table 5. Combination of respondents' preferences.

\begin{tabular}{|c|c|c|c|c|c|c|c|c|c|c|c|}
\hline \multirow[t]{2}{*}{ No. } & \multirow[t]{2}{*}{ Biodiversity } & \multirow{2}{*}{$\begin{array}{l}\text { Land Use } \\
\text { Patterns }\end{array}$} & \multirow{2}{*}{$\begin{array}{l}\text { Fishery and Solar } \\
\text { Power Symbiosis } \\
\text { Coverage Ratio }\end{array}$} & \multirow{2}{*}{$\begin{array}{c}\text { Coastal } \\
\text { Landscape }\end{array}$} & \multirow{2}{*}{$\begin{array}{c}\text { Ecocompensation } \\
\text { Fund }\end{array}$} & \multicolumn{2}{|c|}{ Tourists } & \multicolumn{2}{|c|}{$\begin{array}{c}\text { Local } \\
\text { Residents }\end{array}$} & \multicolumn{2}{|c|}{$\begin{array}{l}\text { Aquaculture } \\
\text { Farmers }\end{array}$} \\
\hline & & & & & & $\mathbf{N}$ & $\%$ & $\mathbf{N}$ & $\%$ & $\mathbf{N}$ & $\%$ \\
\hline 1 & $\begin{array}{l}\text { Improving } \\
\text { biodiver- } \\
\text { sity }\end{array}$ & $\begin{array}{l}\text { Maintaining } \\
\text { the status quo }\end{array}$ & $40 \%$ coverage ratio & $\begin{array}{c}\text { Floating solar } \\
\text { power facilities } \\
\text { landscape }\end{array}$ & NT\$500/year & 190 & $23.70 \%$ & 171 & $21.10 \%$ & 79 & $23.30 \%$ \\
\hline 3 & $\begin{array}{l}\text { Maintaining } \\
\text { the } \\
\text { number of } \\
\text { species }\end{array}$ & $\begin{array}{l}\text { Maintaining } \\
\text { the status quo }\end{array}$ & $70 \%$ coverage ratio & $\begin{array}{c}\text { Fixed solar } \\
\text { power facilities } \\
\text { landscape }\end{array}$ & NT\$250/year & 114 & $14.30 \%$ & 126 & $15.50 \%$ & 43 & $12.80 \%$ \\
\hline 6 & $\begin{array}{l}\text { Maintaining } \\
\text { the } \\
\text { number of } \\
\text { species }\end{array}$ & $\begin{array}{l}\text { Maintaining } \\
\text { the status quo }\end{array}$ & $70 \%$ coverage ratio & $\begin{array}{c}\text { Fixed solar } \\
\text { power facilities } \\
\text { landscape }\end{array}$ & NT\$50/year & 97 & $12.10 \%$ & 87 & $10.80 \%$ & 38 & $11.10 \%$ \\
\hline 12 & $\begin{array}{l}\text { Maintaining } \\
\text { the } \\
\text { number of } \\
\text { species }\end{array}$ & $\begin{array}{l}\text { Increasing the } \\
\text { afforestation } \\
\text { area }\end{array}$ & $\begin{array}{c}\text { Coverage ratio of } \\
40 \%\end{array}$ & $\begin{array}{c}\text { Floating solar } \\
\text { power facilities } \\
\text { landscape }\end{array}$ & NT\$250/year & 157 & $19.60 \%$ & 141 & $17.40 \%$ & 60 & $17.80 \%$ \\
\hline 17 & $\begin{array}{l}\text { Improving } \\
\text { biodiver- } \\
\text { sity }\end{array}$ & $\begin{array}{l}\text { Maintaining } \\
\text { the status quo }\end{array}$ & $40 \%$ coverage ratio & $\begin{array}{c}\text { Fixed solar } \\
\text { power facilities } \\
\text { landscape }\end{array}$ & NT\$1,000/year & 58 & $7.20 \%$ & 47 & $5.80 \%$ & 18 & $5.20 \%$ \\
\hline 23 & $\begin{array}{l}\text { Maintaining } \\
\text { the } \\
\text { number of } \\
\text { species }\end{array}$ & $\begin{array}{l}\text { Maintaining } \\
\text { the status quo }\end{array}$ & $0 \%$ coverage ratio & $\begin{array}{l}\text { Aqua farm } \\
\text { landscape }\end{array}$ & NT\$0/year & 89 & $11.10 \%$ & 115 & $14.20 \%$ & 48 & $14.10 \%$ \\
\hline 25 & $\begin{array}{l}\text { Improving } \\
\text { biodiver- } \\
\text { sity }\end{array}$ & $\begin{array}{l}\text { Increasing the } \\
\text { solar panel } \\
\text { area }\end{array}$ & $40 \%$ coverage ratio & $\begin{array}{c}\text { Fixed solar } \\
\text { power facilities } \\
\text { landscape }\end{array}$ & NT\$250/year & 96 & $12.00 \%$ & 123 & $15.20 \%$ & 53 & $15.70 \%$ \\
\hline
\end{tabular}

\subsection{Model Results}

\subsubsection{Explanation of Variables in the Empirical Model}

In this study, Y stands for the alternative scheme variable provided in each choice set; when a respondent chooses a preferred scheme, the value of the scheme variable chosen is set to 1 
$(\mathrm{Y}=1)$. Otherwise, it is set to $0(\mathrm{Y}=0)$. This study has 974 valid questionnaires, producing $6 \times 974=5844$ sets of data for empirical analysis, and the empirical data analysis and estimation adopt the Nlogit 5 and SPSS 22 statistics software as research tools. During data consolidation, to meet the restrictions of the Nlogit software, this study recoded the definition of attributes in the questionnaires. Table 6 provides an explanation of the variable codes of the attribute levels for FSPS and their expected symbol collection.

Table 6. Explanation of variables in the empirical model.

\begin{tabular}{|c|c|c|c|c|}
\hline & Variable Name & $\begin{array}{c}\text { Variable } \\
\text { Designation }\end{array}$ & Variable Code & $\begin{array}{c}\text { Expected } \\
\text { Symbol }\end{array}$ \\
\hline \multirow{9}{*}{$\begin{array}{l}\text { Attribute level } \\
\text { value }\end{array}$} & \multirow{2}{*}{ Biodiversity } & $\mathrm{BD}_{1}$ & $\begin{array}{l}\text { " }-1 \text { " stands for maintaining the number of species } \\
\text { " } 1 \text { " stands for improving biodiversity } \\
\text { " } 0 \text { " stands for reducing biodiversity }\end{array}$ & + \\
\hline & & $\mathrm{BD}_{2}$ & $\begin{array}{l}\text { " }-1 \text { " stands for maintaining the number of species } \\
\text { " } 1 \text { " stands for reducing biodiversity } \\
\text { " } 0 \text { " stands for improving biodiversity }\end{array}$ & - \\
\hline & \multirow{2}{*}{$\begin{array}{l}\text { Land use } \\
\text { pattern }\end{array}$} & $\mathrm{LU}_{1}$ & $\begin{array}{l}\text { " }-1 \text { " stands for maintaining the status quo } \\
\text { " } 1 \text { " stands for increasing afforestation area } \\
\text { " } 0 \text { " stands for increasing the solar panel area }\end{array}$ & + \\
\hline & & $\mathrm{LU}_{2}$ & $\begin{array}{l}\text { " }-1 \text { " stands for maintaining the status quo } \\
\text { " } 1 \text { " stands for increasing the solar panel area } \\
\text { " } 0 \text { " stands for increasing afforestation area }\end{array}$ & - \\
\hline & \multirow{2}{*}{$\begin{array}{l}\text { Fishery and } \\
\text { solar power } \\
\text { symbiosis } \\
\text { coverage ratio }\end{array}$} & $\mathrm{SH}_{1}$ & $\begin{array}{l}\text { " }-1 \text { " stands for the } 0 \% \text { coverage ratio } \\
\text { " } 1 \text { " stands for the } 40 \% \text { coverage ratio } \\
\text { " } 0 \text { " stands for the } 70 \% \text { coverage ratio }\end{array}$ & - \\
\hline & & $\mathrm{SH}_{2}$ & $\begin{array}{l}\text { " }-1 \text { " stands for the } 0 \% \text { coverage ratio } \\
\text { " } 1 \text { " stands for the } 70 \% \text { coverage ratio } \\
\text { " } 0 \text { " stands for the } 40 \% \text { coverage ratio }\end{array}$ & - \\
\hline & \multirow{2}{*}{$\begin{array}{l}\text { Coastal } \\
\text { landscape }\end{array}$} & $\mathrm{PN}_{1}$ & $\begin{array}{l}\text { " }-1 \text { " stands for the aqua farm landscape } \\
\text { " } 1 \text { " stands for the fixed solar power facilities landscape } \\
\text { " } 0 \text { " stands for the floating solar power facilities landscape }\end{array}$ & - \\
\hline & & $\mathrm{PN}_{2}$ & $\begin{array}{l}\text { " }-1 \text { " stands for the aqua farm landscape } \\
\text { " } 1 \text { " stands for the floating solar power facilities landscape } \\
\text { " } 0 \text { " stands for the fixed solar power facilities landscape }\end{array}$ & + \\
\hline & $\begin{array}{l}\text { Ecocompensation } \\
\text { fund }\end{array}$ & CS & $\begin{array}{l}\text { “0” stands for NT\$0/year } \\
\text { “250” stands for NT\$250/year } \\
\text { “500” stands for NT\$500/year } \\
\text { “750" stands for NT\$750/year } \\
\text { “1000” stands for NT\$1000/year }\end{array}$ & - \\
\hline
\end{tabular}

\subsubsection{Multinomial Logit Results}

According to the likelihood estimation function of the MNL model, Formula (9), this study establishes an ecosystem conservation preference utility model to examine the respondents' preferences for the FSPS policy.

Based on the survey results, pseudotransformation is conducted to the attribute level values and respondents' socioeconomic background variables; two MNL models are used to analyze the statistical data. Model 1 considers the choice attributes and their levels, and Model 2 covers the respondents' personal information, as shown in Table 7. The P values of the five attributes in Models 1 and 2 are less than 0.01 , including the biodiversity, land use patterns, FSPS coverage ratio, coastal landscape, and ecocompensation fund. This shows that the questionnaire design has statistical significance; the likelihood function value (log likelihood), PseudoR2, and AIC/N in Table 7 show that the collocation degree of Model 2 is better than Model 1 for each of the respondents. Therefore, for this study, adding the respondents' demographic variables in the model is better for explaining the findings; accordingly, Model 2 was adopted for data analysis to meet the actual situation. However, 
after analyzing the preference degrees of the respondents in terms of the FSPS attributes, the expected results and symbols of the coefficient values of all attribute variables were found to correspond. The coefficient values of improving biodiversity $\left(\mathrm{BD}_{1}\right)$, increasing the afforestation area $\left(\mathrm{LU}_{1}\right)$, and enhancing the floating solar power facilities landscape $\left(\mathrm{PN}_{2}\right)$ are positive, meaning that each unit of increase in these attribute levels will increase the benefits for tourists, local residents, and aquaculture farmers. Conversely, for reducing biodiversity $\left(\mathrm{BD}_{2}\right)$, increasing the area of solar facilities $\left(\mathrm{LU}_{2}\right)$, and settling for a $40 \%$ solar panel coverage ratio $\left(\mathrm{SH}_{1}\right), 70 \%$ solar panel coverage ratio $\left(\mathrm{SH}_{2}\right)$, and fixed solar power facilities landscape $\left(\mathrm{PN}_{1}\right)$, the coefficient values are negative. This shows that each unit of increase in these attribute levels will reduce the benefits.

\subsubsection{Willingness to Pay Measures}

This study assumes that when other attribute levels are not changed, the MWTP of a certain attribute relative to the level can be estimated, and the WTP for each attribute is the individual MWTP that can reflect the protection fee a respondent is willing to pay for the improvement of certain attribute levels, i.e., the implicit price of the attribute. The marginal price levels of the attributes are calculated according to Formula (10), as shown in Table 8. Improving biodiversity has the highest MWTP from the respondents, meaning that each group believes that the ecocompensation cost shall, for the most part, be allocated to the improvement of biodiversity. Recent studies have acknowledged the importance of the integration between the dimensions of biodiversity conservation and protection of ecosystem services [57]. Ecosystem services and functions depend on, and are highly sensitive to, the quality of biodiversity [58].

Improvement of the fixed solar power facilities has the second highest MWTP; however, its coefficient is negative, showing that the fixed solar power facilities have great negative influences on the tourists, local residents, and aquaculture farmers. Avoidance of solar panel coverage ratio had the lowest MWTP, showing that this attribute level is least important for them. However, based on the study surveys, the respondents' knowledge about FSPS is between "slightly known" to "known" Moreover, the differences in coverage ratios of FSPS can only be felt upon completion, so this study deduces that the respondents cannot assess the differences between high and low coverage ratios because of the reasons above, causing low MWTP. 
Table 7. Multinomial logit empirical estimation results.

\begin{tabular}{|c|c|c|c|c|c|c|c|c|c|c|c|c|c|c|c|c|c|c|}
\hline \multirow[b]{2}{*}{$\begin{array}{c}\text { Variable } \\
\text { Designa- } \\
\text { tion }\end{array}$} & \multicolumn{3}{|c|}{ Model 1-Tourists } & \multicolumn{3}{|c|}{ Model 2-Tourists } & \multicolumn{3}{|c|}{ Model 1-Local Residents } & \multicolumn{3}{|c|}{ Model 2-Local Residents } & \multicolumn{3}{|c|}{ Model 1-Aquaculture Farmers } & \multicolumn{3}{|c|}{ Model 2-Aquaculture Farmers } \\
\hline & Coefficient & $\begin{array}{l}\text { Standard } \\
\text { Error }\end{array}$ & $p$ Value & Coefficient & $\begin{array}{l}\text { Standard } \\
\text { Error }\end{array}$ & $p$ Value & Coefficient & $\begin{array}{l}\text { Standard } \\
\text { Error }\end{array}$ & $p$ Value & Coefficient & $\begin{array}{l}\text { Standard } \\
\text { Error }\end{array}$ & $p$ Value & Coefficient & $\begin{array}{l}\text { Standard } \\
\text { Error }\end{array}$ & $p$ Value & Coefficient & $\begin{array}{l}\text { Standard } \\
\text { Error }\end{array}$ & $p$ Value \\
\hline $\mathrm{BD}_{1}$ & 0.2666 & 0.1883 & 0.0000 & 0.3102 & 0.1624 & 0.0000 & 0.2832 & 0.1773 & 0.0000 & $0.3302 * * *$ & 0.1524 & 0.0000 & 0.3012 & 0.2081 & 0.0000 & 0.3413 & 0.1734 & 0.0000 \\
\hline $\mathrm{BD}_{2}$ & $-\underset{* * *}{0.2337}$ & 0.1592 & 0.0000 & $-\underset{* * *}{0.2584}$ & 0.1133 & 0.0000 & $-\underset{* * *}{0.2526}$ & 0.1698 & 0.0000 & $-0.2484^{* * *}$ & 0.1122 & 0.0000 & $-\underset{* * *}{0.2782}$ & 0.1778 & 0.0000 & -0.2722 & 0.1211 & 0.0000 \\
\hline $\mathrm{LU}_{1}$ & $0.2314^{* *}$ & 0.2149 & 0.0029 & $\underset{* * *}{0.2013}$ & 0.1149 & 0.0007 & $0.2422 * *$ & 0.2203 & 0.0021 & $0.2113^{* * *}$ & 0.1433 & 0.0000 & 0.2023 ** & 0.2236 & 0.0018 & $\underset{* * *}{0.2501}$ & 0.1333 & 0.0000 \\
\hline $\mathrm{SH}_{1}$ & -0.1921 & 0.1712 & 0.0000 & $\underset{* * *}{-0.1954}$ & -0.1338 & 0.0000 & -0.1893 & 0.1773 & 0.0000 & $-0.1854^{* * *}$ & 0.1711 & 0.0000 & $-\underset{* * *}{-0.2022}$ & 0.1812 & 0.0000 & $-\underset{* * *}{0.1933}$ & 0.1347 & 0.0000 \\
\hline $\mathrm{SH}_{2}$ & $-\underset{* * *}{0.1830}$ & 0.1821 & 0.0000 & $-\underset{* * *}{0.1666}$ & 0.1702 & 0.0000 & $-\underset{* * *}{0.1663}$ & 0.1779 & 0.0000 & $-0.1616^{* * *}$ & 0.1659 & 0.0000 & -0.1778 & 0.1889 & 0.0000 & -0.1473 & 0.1221 & 0.0000 \\
\hline $\mathrm{PN}_{1}$ & $-\underset{* * *}{0.2602}$ & 0.1333 & 0.0000 & $-\underset{* * *}{0.2884}$ & 0.1221 & 0.0001 & $-\underset{* * *}{0.2732}$ & 0.1428 & 0.0000 & $-0.2784 * * *$ & 0.1331 & 0.0002 & $-\underset{* * *}{0.2893}$ & 0.1983 & 0.0000 & $-\underset{* * *}{0.2733}$ & 0.1219 & 0.0000 \\
\hline $\mathrm{PN}_{2}$ & $\underset{* * *}{0.2111}$ & 0.1346 & 0.0007 & $\underset{* * *}{0.2776}$ & 0.1537 & 0.0004 & $\underset{* * *}{0.2202}$ & 0.1336 & 0.0000 & $0.2674^{* * *}$ & 0.1222 & 0.0003 & 0.2022 & 0.1788 & 0.0000 & 0.2630 & 0.1417 & 0.0004 \\
\hline EDU & & & & 0.3511 & 0.1732 & 0.0001 & & & & 0.3001 ** & 0.1665 & 0.0021 & & & & 0.2701 & 0.1771 & 0.1713 \\
\hline IC & & & & 0.1049 & 0.1444 & 0.1778 & & & & 0.1347 & 0.1114 & 0.2333 & & & & 0.1047 & 0.2098 & 0.2103 \\
\hline CS & -0.0012 & 0.0019 & 0.0004 & $-\underset{* * *}{-0.0015}$ & 0.0012 & 0.0002 & $-\underset{* * *}{-0.0011}$ & 0.0016 & 0.0004 & $-0.0014 * * *$ & 0.0022 & 0.0002 & $\underset{* * *}{-0.0007}$ & 0.0019 & 0.0004 & $-\underset{* * *}{-0.0012}$ & 0.0011 & 0.0000 \\
\hline $\begin{array}{l}\text { log likeli- } \\
\text { hood }\end{array}$ & & -547.2678 & & & -389.3281 & & & -533.2338 & & & -367.3311 & & & -443.322 & & & -288.2331 & \\
\hline PseudR $^{2}$ & & 0.1033 & & & 0.2367 & & & 0.1333 & & & 0.1334 & & & 0.1894 & & & 0.2334 & \\
\hline $\mathrm{AIC} / \mathrm{N}$ & & 1.7332 & & & 1.5798 & & & 1.8322 & & & 1.4673 & & & 1.6792 & & & 1.4749 & \\
\hline
\end{tabular}

$* * p<0.01 ; * * * p<0.001$ 
Table 8. MWTP for attributes of the ecosystem conservation preference effect model.

\begin{tabular}{|c|c|c|c|c|c|c|}
\hline \multirow[t]{2}{*}{ Attribute and Variable } & \multicolumn{2}{|c|}{ Tourist } & \multicolumn{2}{|c|}{ Local Resident } & \multicolumn{2}{|c|}{ Aquaculture Farmer } \\
\hline & Coefficient & $\begin{array}{c}\text { MWTP } \\
\text { (NT\$) }\end{array}$ & Coefficient & Coefficient & $\begin{array}{c}\text { MWTP } \\
\text { (NT\$) }\end{array}$ & Coefficient \\
\hline Biodiversity $\left(\mathrm{BD}_{1}\right)$ & $0.3102^{* * *}$ & 206.8 & $0.3302^{* * *}$ & 235.9 & $0.3413^{* * *}$ & 284.4 \\
\hline Biodiversity $\left(\mathrm{BD}_{2}\right)$ & $-0.2584^{* * *}$ & 172.3 & $-0.2484^{* * *}$ & 177.4 & $-0.2722 * * *$ & 226.8 \\
\hline Land use pattern $\left(\mathrm{LU}_{1}\right)$ & $0.2013^{* * *}$ & 134.2 & $0.2113^{* * *}$ & 150.9 & $0.2501^{* * *}$ & 208.4 \\
\hline Land use pattern $\left(\mathrm{LU}_{2}\right)$ & $-0.1714^{* * *}$ & 114.3 & $-0.1664^{* * *}$ & 118.9 & $-0.1833^{* * *}$ & 152.8 \\
\hline FSPS coverage ratio $\left(\mathrm{SH}_{1}\right)$ & $-0.1954^{* * *}$ & 130.3 & $-0.1854^{* * *}$ & 132.4 & $-0.1933^{* * *}$ & 161.1 \\
\hline FSPS coverage ratio $\left(\mathrm{SH}_{2}\right)$ & $-0.1666^{* * *}$ & 111.1 & $-0.1616^{* * *}$ & 115.4 & $-0.1473^{* * *}$ & 122.8 \\
\hline Coastal landscape $\left(\mathrm{PN}_{1}\right)$ & $-0.2884^{* * *}$ & 192.3 & $-0.2784^{* * *}$ & 198.9 & $-0.2733^{* * *}$ & 227.8 \\
\hline Coastal landscape $\left(\mathrm{PN}_{2}\right)$ & $0.2776^{* * *}$ & 185.1 & $0.2674^{* * *}$ & 191.0 & $0.2630^{* * *}$ & 219.2 \\
\hline Ecocompensation fund (CS) & $-0.0015^{* * *}$ & & $-0.0014^{* * *}$ & & $-0.0012^{* * *}$ & \\
\hline
\end{tabular}

$* * * p<0.001$.

\section{Discussion}

This study surveys the tourists, local residents, and aquaculture farmers of Cigu to conduct an integrated multi-attribute preference analysis on past wetland ecosystem conservation and ecocompensation. Further, by referring to relevant studies on the ecological service system and current policy planning data, five sets of attributes and levels of FSPS are set using CEM, and the findings are obtained from the studies above by estimating the MWTP of the respondents with the MNL model.

\subsection{Combination of Choices Preferred by Respondents}

The study findings are the same as those of Wen et al. [52] and Lee et al. [53] regarding the visual impact on the landscape leading to objections against implementation from the local residents. As for the ecocompensation fund (NT\$1000/year), Ntanos et al. [59] indicated that Greek households are willing to pay $€ 8.8$ (approximately NT\$303) extra every month to develop renewable energy. Bigerna and Polinori [60] revealed that Italian households are willing to pay $€ 4.62-8.05$ (approximately NT\$159-277) every season to develop green energy. Xie and Zhao [61] showed that the mainland Chinese are willing to pay US\$4.73 (approximately NT\$142) every month to support the development of green energy. Koto and Yiridoe [62] showed that Canadian residents are willing to pay CAD\$8 (approximately NT\$177) every month to develop wind power generation. The WTP for FSPS of the respondents in $\mathrm{Cigu}$, Taiwan is lower than that in other countries. Moreover, Suziana [43] showed that the concern regarding the environmental issues of a Malaysian wetland influences respondents' WTP; hence, this study believes that the respondents' concern regarding environmental issues will influence their WTP for the development of FSPS.

The findings show that, with FSPS and the ecocompensation fund in parallel, the ecosystem of the environment must be considered during the construction of the solar power generation facilities. Moreover, the respondents hope that the FSPS can be conducted with smaller changes to the status quo. The improvement in biodiversity is the attribute level with the highest MWTP, similar to the findings of Shoyama et al. [63] on environmental compensation in Hokkaido, Japan, which showed that people are willing to pay additional fees to protect biodiversity and endangered species. A study by Lee et al. [64] showed that people are willing to pay KRW197 and 138 (US\$0.18 and US\$0.13), respectively, to obtain a $1 \%$ visual impact improvement and ecosystem damage compensation. Kunwar et al. [65] revealed that Nepalese households are willing to pay US\$1.63/year to recover the river ecosystem service, which is similar to the findings of this study.

The differences between the most and least preferred ones include "fixed solar power facilities landscape" and "the ecocompensation fund of NT\$1000/year." Therefore, this study deduces that the respondents believe that a fixed solar power facilities landscape has relatively huge impacts on scenic 
spots for tourists, the quality of life of local residents, and aquaculture status of the farmers. This is similar to the findings by Lee et al. [53] that some in the public believe that beautiful natural scenes are more important than sustainable natural ecosystems. Peri et al. [66] adopted CEM to survey the preferences of Israelis regarding wind power generation and showed that visual impacts, land use patterns, shadow generation, noise degree, and bird-harm frequency have significant influences, which is similar to our findings.

\subsection{Discussion on Differences of Respondents}

Comparing our results with other studies shows that our WTP estimates are within a similar range, although they are at the lower end of the largely scattered values for recreational and habitat services [67-69]. In a recently compiled database with more than 20 studies on biodiversity conservation, most WTP estimates range between US\$100 and 800 per year in Switzerland [70]. While many of these studies applied similar SP techniques, such as CVM or CEM, results vary from 11.99 euro/year (14.14 USD/year) in Italy [71] to over 718.95 euro/year (848.14 USD/year) in the Greek Aegean Islands [72]. This spread demonstrates that the results of WTP studies are highly context- and method-dependent, which exacerbates comparison with, and transfer to, other study sites.

Cigu has ecosystem service functions, such as ecosystem conservation, aquaculture, fisheries, and green power generation development. This study provides recommendations for policies by discussing the differences of the respondents. The findings show that knowledge of the aquaculture farmers about "FSPS" and "ecocompensation" is better than that of local residents and tourists, and Table 8 shows that WTP of the aquaculture farmers for the ecocompensation fund is higher than WTP of the local residents and the tourists. Therefore, this study deduces that aquaculture farmers are most directly influenced by solar panels, so they pay more attention to the issue and are willing to pay more to protect the environment. Farmers with better knowledge are expected to have a positive perception and attitude toward better environmental management and cleaner production, which, in turn, is expected to lead to higher WTP [73]. Our results also confirmed this positive relationship. Futhermore, the findings are consistent with that of Bartczak [74] wherein WTP of the Polish people for forest ecosystem conservation increases with an increase in environmental concern.

Conversely, this study finds that gender and education level of the tourists and local residents influence their choice preferences and, therefore, deduces that women give more importance to environment conservation (similar to $[75,76]$ ) and those with higher education have better awareness of sustainable development (similar to $[77,78]$ ). However, this phenomenon does not exist among aquaculture farmers. This study believes that aquaculture farmers are mainly men with high school education (vocational school), so there is no statistical significance; similarly, [79] found men to be less interested in environmental protection. Education also appears to be crucial in affecting environmental WTP. Highly educated people show higher levels of concern about the environment $[77,78]$. Therefore, relevant preferential activities can be provided, such as teacher certificate discounts, postgraduate discounts, student discounts and women-related products, etc.

\section{Conclusions}

\subsection{Findings}

Ecosystem service valuation is concerned with determining the combinations of ecological and economic indicators. Economic benefits are often underestimated because the potential contribution of wetland ecosystem services to regional sustainable development is unclear. Through public feedback quantification using various methods, combined with land use pattern changes, the monetary value of wetland ecosystem services can be calculated. The effects of these ecological policies can be transformed into economic benefits or losses, which will provide an important reference for the tradeoff for future policy implications. This study provides the following conclusions based on the respondents' ecocompensation preferences: (1) tourists' knowledge about FSPS and environment compensation is limited, so their MWTP is lower than that of local residents and aquaculture farmers; (2) tourists, local residents, and aquaculture farmers believe that it is important to improve biodiversity; (3) tourists, local residents, and aquaculture farmers prefer the implementation of FSPS with minimal change in the status quo. 


\subsection{Recommendations}

Based on the aforementioned conclusions, the present study provides the following recommendations:

1. The government should plan special FSPS areas in recreational scenic spots to educate tourists about the operational manner and purpose of FSPS through models, educational programs and promotional videos and collect tourists' comments for improving future administration;

2. FSPS's influences on the original ecosystem services are inevitable, but the harm can be remedied and recovered with ecocompensation, which is acceptable to most respondents. Therefore, this study recommends that in reviewing FSPS cases, the government should evaluate the maintenance plan for environmental conservation after implementation and assessment of some aspects of the ecocompensation fund, including effectiveness, reasonableness, and sustainability;

3. Tourists, local residents, and aquaculture farmers prefer maintaining the status quo of the land use pattern, and this is reflected in that most respondents prefer "ecological remediation" to "ecosystem creation". Therefore, the land use pattern of FSPS should follow the principle of maintaining the status quo and achieve biodiversity improvement through ecological remediation.

\subsection{Directions for Future Studies}

Because the FSPS policy of Cigu involves a highly sensitive and complex environment, the attributes and levels adopted in the study cannot cover all the contents of policy planning. Moreover, the FSPS policy of Cigu is restricted by the techniques used for installation, so it is impossible to conduct practice directly according to opinions from a single standpoint. Therefore, this study plans to invite personnel in FSPS-relevant units, as well as conservation group members, to discuss the aspects needing improvement and add the issue of solar panel recovery to achieve the ultimate goal of sustainability. Additionally, we can use technologies and tools such as virtual reality, augmented reality and mixed reality to let people know how irreplaceable nature is.

Conversely, the MNL model used in this study can be changed into a latent class model in future studies to inspect whether the respondents have heterogeneous preferences for the attribute levels designed in the study to conduct a more comprehensive analysis and discussion of the ecosystem conservation issue.

Author Contributions: H.-S.C., the first author, analyzed the data, drafted the manuscript, and acted as corresponding author throughout the submission and revision. H.-Y.K. contributed to reviewing and revising the literature. All authors have read and agreed to the published version of the manuscript.

Funding: This work was funded by the Ministry of Science and Technology (Taiwan), Grant Number MOST 109-2410-H-040-011-SS2. The funder had no role in the study design; collection, analysis and interpretation of data; writing the report; or the decision to submit the article for publication.

Institutional Review Board Statement: Not applicable.

Informed Consent Statement: Not applicable.

Data Availability Statement: The data that support the findings of this study are available from the corresponding author, H.-S.C., upon reasonable request.

Acknowledgments: We would like to express our sincere appreciation to all the experts who have taken the time to review this article and provide their valuable comments.

Conflicts of Interest: The authors declare no conflict of interest.

\section{References}

1. Woo, J.; Chung, S.; Lee, C.Y.; Huh, S.Y. Willingness to participate in community-based renewable energy projects: A contingent valuation study in South Korea. Renew. Sustain. Energy Rev. 2019, 112, 643-652. [CrossRef]

2. Baldwin, E.; Carley, S.; Nicholson-Crotty, S. Why do countries emulate each others' policies? A global study of renewable energy policy diffusion. World Dev. 2019, 120, 29-45. [CrossRef] 
3. Swain, R.B.; Karimu, A. Renewable electricity and sustainable development goals in the EU. World Dev. $2020,125,104693$. [CrossRef]

4. Bigerna, S.; Bollino, C.A.; Micheli, S. Renewable energy scenarios for costs reductions in the European Union. Renew. Energy 2016, 96, 80-90.

5. Connolly, D.; Lund, H.; Mathiesen, B.V. Smart energy Europe: The technical and economic impact of one potential $100 \%$ renewable energy scenario for the European Union. Renew. Sustain. Energy Rev. 2016, 60, 1634-1653. [CrossRef]

6. Kemfert, C. Germany must go back to its low-carbon future. Nature 2017, 549, 26-27. [CrossRef]

7. Hong, S.; Brook, B.W. A nuclear-to-gas transition in South Korea: Is it environmentally friendly or economically viable? Energy Policy 2018, 112, 67-73. [CrossRef]

8. Taipower. Power Generation Information. Available online: https://www.taipower.com.tw/tc/page.aspx?mid=204 (accessed on 11 May 2021).

9. Taiyen Green Energy. What Is Fisheries and Solar Power Symbiosis. Available online: https://www.tygreen.com.tw/faq/3/ (accessed on 11 March 2021).

10. Fishery Office, Agriculture Committee of the Executive Yuan of Taiwan. 2019. Available online: https://fadopen.fa.gov.tw/ fadopen/service/qrySpeciesSummaryYearlyReport.htmx (accessed on 11 May 2021).

11. Spellman, F.R. Environmental Impacts of Renewable Energy; Taylor \& Francis Group: Boca Raton, FL, USA, 2014.

12. Hernandez, R.R.; Hoffacker, M.K.; Murphy-Mariscal, M.L.; Wu, G.C.; Allen, M.F. Solar energy development impacts on land cover change and protected areas. Proc. Natl. Acad. Sci. USA 2015, 112, 13579-13584. [CrossRef]

13. Dhar, A.; Naeth, M.A.; Jennings, P.D.; El-Din, M.G. Perspectives on environmental impacts and a land reclamation strategy for solar and wind energy systems. Sci. Total Environ. 2020, 718, 134602. [CrossRef] [PubMed]

14. Bennett, M.T.; Gong, Y.; Scarpa, R. Hungry birds and angry farmers: Using choice experiments to assess "eco-compensation" for coastal wetlands protection in China. Ecol. Econ. 2018, 154, 71-87. [CrossRef]

15. Staples, A.J.; Reeling, C.J.; Widmar, N.J.O.; Lusk, J.L. Consumer willingness to pay for sustainability attributes in beer: A choice experiment using eco-labels. Agribusiness 2020, 36, 591-612. [CrossRef]

16. Dauda, S.; Sidique, S.F.; Sheng, T.Y.; Djama, M. Consumer Preference for Certified Sustainable Palm Oil with Environmental Sustainability Attributes: A Choice Experiment Approach. Stud. Appl. Econ. 2021, 39. [CrossRef]

17. Kim, J.H.; Kim, Y.; Yoo, S.H. Using a choice experiment to explore the public willingness to pay for the impacts of improving energy efficiency of an apartment. Qual. Quant. 2021, 55, 1775-1793. [CrossRef]

18. Liu, J.; Dou, S.; Hmeimar, A.E.H. Cost-effectiveness analysis of different types of payments for ecosystem services: A case in the urban wetland ecosystem. J. Clean. Prod. 2020, 249, 119325.

19. TEEB. The Economics of Ecosystems and Biodiversity: Ecological and Economic Foundations; Kumar, P., Ed.; Earthscan Publications: London, UK; Washington, DC, USA, 2010.

20. Muradian, R.; Corbera, E.; Pascual, U.; Kosoy, N.; May, P.H. Reconciling theory and practice: An alternative conceptual framework for understanding payments for environmental services. Ecol. Econ. 2010, 69, 1202-1208. [CrossRef]

21. Kumar, P.; Kumar, M.; Garrett, L. Behavioural foundation of response policies for ecosystem management: What can we learn from payments for ecosystem services (PES). Ecosyst. Serv. 2014, 10, 128-136. [CrossRef]

22. Japelj, A.; Mavsar, R.; Hodges, D.; Kovač, M.; Juvančič, L. Latent preferences of residents regarding an urban forest recreation setting in Ljubljana, Slovenia. Forest Policy Econ. 2016, 71, 71-79. [CrossRef]

23. King, D.M.; Mazzotta, M.; Markowitz, K.J. Ecosystem Valuation. 2000. Available online: https://ecosystemvaluation.org/ (accessed on 19 October 2021).

24. Mark, T.L.; Swait, J. Using stated preference and revealed preference modeling to evaluate prescribing decisions. Health Econ. 2004, 13, 563-573. [CrossRef] [PubMed]

25. Choi, A.S.; Ritchie, B.W.; Papandrea, F.; Bennett, J. Economic valuation of cultural heritage sites: A choice modeling approach. Tourism Manag. 2010, 31, 213-220. [CrossRef]

26. Rudd, R.A. National values for reginal aquatic species at risk in Canada. Endanger. Species Res. 2009, 6, 239-249. [CrossRef]

27. Hoyos, D. The state of the art of environmental valuation with discrete choice experiments. Ecol. Econ. 2010, 69, 1595-1603. [CrossRef]

28. Jaung, W.; Putzel, L.; Bull, G.Q.; Guariguata, M.R.; Sumaila, U.R. Estimating demand for certification of forest ecosystem services: A choice experiment with Forest Stewardship Council certificate holders. Ecosyst. Serv. 2016, 22, 193-201. [CrossRef]

29. Rulleau, B.; Dumax, N.; Rozan, A. Eliciting preferences for wetland services: A way to manage conflicting land uses. J. Environ. Plan. Manag. 2017, 60, 309-327. [CrossRef]

30. Liu, T.M.; Yang, W.C. Using choice experiments to inform management of black-faced spoonbill reserve in Taiwan. Cogent Soc. Sci. 2019, 5, 1611984. [CrossRef]

31. Xi, Z.; Xu, W.; Wei, Q. Value attributes and user preferences for the coastal wetland ecosystem in Caofeidian, China. IOP Conf. Ser. Mater. Sci. Eng. 2018, 392, 042017. [CrossRef]

32. Huang, Y.S.; Chen, Y.J.; Ting, C.T. Estimation the preference of ecotourism for Gaomei wetland in Taiwan. EcoForum J. 2018, 7, 14.

33. Owuor, M.A.; Mulwa, R.; Otieno, P.; Icely, J.; Newton, A. Valuing mangrove biodiversity and ecosystem services: A deliberative choice experiment in Mida Creek, Kenya. Ecosyst. Serv. 2019, 40, 101040. [CrossRef] 
34. Mao, B.; Ao, C.; Wang, J.; Xu, L. The importance of loss aversion in public preferences for wetland management policies: Evidence from a choice experiment with reference-dependent discrete choice model. Wetlands 2020, 40, 599-608. [CrossRef]

35. Hassan, S.; Olsen, S.B.; Thorsen, B.J. Urban-rural divides in preferences for wetland conservation in Malaysia. Land Use Policy 2019, 84, 226-237. [CrossRef]

36. Kim, K.J.; Lee, H.; Koo, Y. Research on local acceptance cost of renewable energy in South Korea: A case study of photovoltaic and wind power projects. Energy Policy 2020, 144, 111684. [CrossRef]

37. Zhao, Q.; Bai, J.; Huang, L.; Gu, B.; Lu, Q.; Gao, Z. A review of methodologies and success indicators for coastal wetland restoration. Ecol. Indic. 2016, 60, 442-452. [CrossRef]

38. Tan, Y.; Lv, D.; Cheng, J.; Wang, D.; Mo, W.; Xiang, Y. Valuation of environmental improvements in coastal wetland restoration: A choice experiment approach. Glob. Ecol. Conserv. 2018, 15, e00440. [CrossRef]

39. Chen, W.; Cao, C.; Liu, D.; Tian, R.; Wu, C.; Wang, Y.; Qian, Y.; Ma, G.; Bao, D. An evaluating system for wetland ecological health: Case study on nineteen major wetlands in Beijing-Tianjin-Hebei region, China. Sci. Total Environ. 2019, 666, 1080-1088. [CrossRef] [PubMed]

40. Barbier, E.B.; Koch, E.W.; Silliman, B.R.; Hacker, S.D.; Wolanski, E.; Primavera, J.; Granek, E.F.; Polasky, S.; Aswani, S.; Cramer, L.A.; et al. Coastal ecosystem-based management with nonlinear ecological functions and values. Science 2008, 319, 321-323. [CrossRef]

41. Barbier, E.B.; Hacker, S.D.; Kennedy, C.; Koch, E.W.; Stier, A.C.; Silliman, B.R. The value of estuarine and coastal ecosystem services. Ecol. Monogr. 2011, 81, 169-193. [CrossRef]

42. Himes-Cornell, A.; Pendleton, L.; Atiyah, P. Valuing ecosystem services from blue forests: A systematic review of the valuation of salt marshes, sea grass beds and mangrove forests. Ecosyst. Serv. 2018, 30, 36-48. [CrossRef]

43. Suziana, H. Environmental attitudes and preference for wetland conservation in Malaysia. J. Nat. Conserv. 2017, 37, 133-145. [CrossRef]

44. Liekens, I.; Schaafsma, M.; De Nocker, L.; Broekx, S.; Staes, J.; Aertsens, J.; Brouwer, R. Developing a value function for nature development and land use policy in Flanders, Belgium. Land Use Policy 2013, 30, 549-559. [CrossRef]

45. Boavida-Portugal, I.; Rocha, J.; Ferreira, C.C. Exploring the impacts of future tourism development on land use/cover changes. Appl. Geogr. 2016, 77, 82-91. [CrossRef]

46. Quintas-Soriano, C.; Castro, A.J.; Castro, H.; García-Llorente, M. Impacts of land use change on ecosystem services and implications for human well-being in Spanish drylands. Land Use Policy 2016, 54, 534-548. [CrossRef]

47. Erb, K.H. How a socio-ecological metabolism approach can help to advance our understanding of changes in land-use intensity. Ecol. Econ. 2012, 76, 8. [CrossRef] [PubMed]

48. Dai, J.; Zhang, C.; Lim, H.V.; Ang, K.K.; Qian, X.; Wong, J.L.H.; Tan, S.T.; Wang, C.L. Design and construction of floating modular photovoltaic system for water reservoirs. Energy 2020, 191, 116549. [CrossRef]

49. Shao, W.; Liu, J.; Zhu, M.; Weng, B.; Wang, N.; Huang, H.; Yu, Y.; Yan, D.; Jiang, S. Evaluation of a photovoltaic water-supply scheme for the surface water system in Xiamen, China. Appl. Energy 2018, 230, 357-373. [CrossRef]

50. Spencer, R.S.; Macknick, J.; Aznar, A.; Warren, A.; Reese, M.O. Floating photovoltaic systems: Assessing the technical potential of photovoltaic systems on man-made water bodies in the continental United States. Environ. Sci. Technol. 2019, 53, 1680-1689. [CrossRef] [PubMed]

51. Taboada, M.E.; Cáceres, L.; Graber, T.A.; Galleguillos, H.R.; Cabeza, L.F.; Rojas, R. Solar water heating system and photovoltaic floating cover to reduce evaporation: Experimental results and modeling. Renew. Energy 2017, 105, 601-615. [CrossRef]

52. Wen, C.; Dallimer, M.; Carver, S.; Ziv, G. Valuing the visual impact of wind farms: A calculus method for synthesizing choice experiments studies. Sci. Total Environ. 2018, 637-638, 58-68. [CrossRef]

53. Lee, H.J.; Yoo, S.H.; Huh, S.Y. Public perspectives on reducing the environmental impact of onshore wind farms: A discrete choice experiment in South Korea. Environ. Sci. Pollut. Res. Int. 2020, 27, 25582-25599. [CrossRef]

54. Kermagoret, C.; Levrel, H.; Carlier, A.; Dachary-Bernard, J. Individual preferences regarding environmental offset and welfare compensation: A choice experiment application to an offshore wind farm project. Ecol. Econ. 2016, 129, 230-240. [CrossRef]

55. Westerberg, V.; Jacobsen, J.B.; Lifran, R. The case for offshore wind farms, artificial reefs and sustainable tourism in the French Mediterranean. Tourism Manag. 2013, 34, 172-183. [CrossRef]

56. Alalwan, A.A. Mobile food ordering apps: An empirical study of the factors affecting customer e-satisfaction and continued intention to reuse. Int. J. Inf. Manag. 2020, 50, 28-44. [CrossRef]

57. Egoh, B.N.; Reyers, B.; Carwardine, J.; Bode, M.; O’Farrell, P.J.; Wilson, K.A.; Possingham, H.P.; Rouget, M.; de Lange, W.; Richardson, D.M.; et al. Safeguarding biodiversity and ecosystem services in the Little Karoo, South Africa. Conserv. Biol. 2010, 24, 1021-1030. [CrossRef]

58. Haines-Young, R.; Potschin, M. The links between biodiversity, ecosystem services and human well-being. In Ecosystem Ecology: A New Synthesis; Raffaelli, D., Frid, C., Eds.; Cambridge University Press: Cambridge, UK, 2010; pp. 110-139.

59. Ntanos, S.; Kyriakopoulos, G.; Chalikias, M.; Arabatzis, G.; Skordoulis, M. Public perceptions and willingness to pay for renewable energy: A case study from Greece. Sustainability 2018, 10, 687. [CrossRef]

60. Bigerna, S.; Polinori, P. Italian households' willingness to pay for green electricity. Renew. Sustain. Energy Rev. 2014, 34, 110-121. [CrossRef] 
61. Xie, B.C.; Zhao, W. Willingness to pay for green electricity in Tianjin, China: Based on the contingent valuation method. Energy Policy 2018, 114, 98-107. [CrossRef]

62. Koto, P.S.; Yiridoe, E.K. Expected willingness to pay for wind energy in Atlantic Canada. Energy Policy 2019, 129, 80-88. [CrossRef]

63. Shoyama, K.; Managi, S.; Yamagata, Y. Public preferences for biodiversity conservation and climate-change mitigation: A choice experiment using ecosystem services indicators. Land Use Policy 2013, 34, 282-293. [CrossRef]

64. Lee, H.J.; Yoo, S.H.; Huh, S.Y. Economic benefits of introducing LNG-fuelled ships for imported flour in South Korea. Transp. Res. D 2020, 78, 102220. [CrossRef]

65. Kunwar, S.B.; Bohara, A.K.; Thacher, J. Public preference for river restoration in the Danda Basin, Nepal: A choice experiment study. Ecol. Econ. 2020, 175, 106690. [CrossRef]

66. Peri, E.; Becker, N.; Tal, A. What really undermines public acceptance of wind turbines? A choice experiment analysis in Israel. Land Use Policy 2020, 99, 105113. [CrossRef]

67. Müller, A.; Olschewski, R.; Unterberger, C.; Knoke, T. The valuation of forest ecosystem services as a tool for management planning-A choice experiment. J. Environ. Manag. 2020, 271, 111008. [CrossRef] [PubMed]

68. Borchers, A.M.; Duke, J.M.; Parsons, G.R. Does willingness to pay for green energy differ by source? Energy Policy 2007, 35, 3327-3334. [CrossRef]

69. Lee, C.Y.; Lee, M.K.; Yoo, S.H. Willingness to pay for replacing traditional energies with renewable energy in South Korea. Energy 2017, 128, 284-290. [CrossRef]

70. Müller, A.; Knoke, T.; Olschewski, R. Can existing estimates for ecosystem service values inform forest management? Forests 2019, 10, 132. [CrossRef]

71. Strazzera, E.; Mura, M.; Contu, D. Combining choice experiments with psychometric scales to assess the social acceptability of wind energy projects: A latent class approach. Energy Policy 2012, 48, 334-347. [CrossRef]

72. Dimitropoulos, A.; Kontoleon, A. Assessing the determinants of local acceptability of wind-farm investment: A choice experiment in the Greek Aegean Islands. Energy Policy 2009, 37, 1842-1854. [CrossRef]

73. Luhmann, N. The world society as a social system. Int. J. Gen. Syst. 1982, 8, 131-138.

74. Bartczak, A. The role of social and environmental attitudes in non-market valuation. Forest Policy Econ. 2015, 50, 357-365. [CrossRef]

75. Torgler, B.; Garcia-Valiñas, M.A. The determinants of individuals' attitudes towards preventing environmental damage. Ecol. Econ. 2007, 63, 536-552. [CrossRef]

76. Israel, D.; Levinson, A. Willingness to pay for environmental quality: Testable empirical implications of the growth and environment literature. Contrib. Econ. Anal. Policy 2004, 3, 31. [CrossRef]

77. Ning, J.; Jin, J.; Kuang, F.; Wan, X.; Zhang, C.; Guan, T. The valuation of grassland ecosystem services in Inner Mongolia of China and its spatial differences. Sustainability 2019, 11, 7117. [CrossRef]

78. Burch, C.; Busch, M.; Higgins, E.; Bittner, S.; Perera, N.; Neal, K.; Burkett, L.; Castro, A.; Anderson, C. Revisiting a water conflict in southeastern Oklahoma 6 years later: A new valuation of the willingness to pay for ecosystem services. Sustainability 2020, 12, 819. [CrossRef]

79. Kollmann, A.; Reichl, J.; Schneider, F. Who is willing to pay for the environment in the EU-An empirical analysis. EuroEconomica 2013, 31, 15-27. 